\title{
ARTICLE
}

\section{Larval development of the southern flounder Thysanopsetta naresi from Chilean Patagonia}

\author{
Desarrollo larval del lenguado austral Thysanopsetta naresi de la Patagonia chilena
}

\section{Cristian Cortez ${ }^{1}$, Fernando Balbontín ${ }^{1}$ and Mauricio F. Landaeta ${ }^{2}$}

\author{
${ }^{1}$ Laboratorio de Ictiología, Facultad de Ciencias del Mar y de Recursos Naturales, Universidad de Valparaíso, Avenida Borgoño \\ 16344, Reñaca, Viña del Mar, Chile. fernando.balbontin@uv.cl \\ ${ }^{2}$ Laboratorio de Ictioplancton (LABITI), Facultad de Ciencias del Mar y de Recursos Naturales, Universidad de Valparaíso, \\ Avenida Borgoño 16344, Reñaca, Viña del Mar, Chile
}

\begin{abstract}
Resumen.- Se describe por primera vez el desarrollo larval del lenguado austral Thysanopsetta naresi, utilizando material proveniente de muestras obtenidas en cruceros oceanográficos realizados en los fiordos del sur de Chile. Las larvas abarcaron un rango de 2,8 a $22,4 \mathrm{~mm}$ de longitud corporal (LC). Un atributo que resalta en las larvas es la fuerte pigmentación, que se desarrolla temprano en preflexión y que se acentúa sobre casi todo el cuerpo, con excepción del extremo caudal. Durante los estadios de postflexión avanzada se identifica un patrón típico de pigmentación en la base de la aleta dorsal y anal. La secuencia de formación de radios en las aletas es caudal, dorsal, anal, pélvica y pectoral. Se describe la secuencia del desarrollo osteológico larval, en particular de las vértebras y del esqueleto caudal. La migración del ojo derecho ocurre desde los $11 \mathrm{~mm}$ LC y la transformación se completa a >23 mm. Los caracteres larvales descritos permiten identificar las larvas de T. naresi y separarlas de las larvas de otras especies de lenguados que se encuentran en la región Patagónica.
\end{abstract}

Palabras clave: Paralichthyidae, larvas de peces, osteología larval, lenguados, fiordos australes

\begin{abstract}
A detailed description of the larval development of the southern flounder Thysanopsetta naresi is carried out for the first time. The study is based on larvae collected in oceanographic cruises carried out in the fjords of southern Chile. The larvae comprised a range from $2.8 \mathrm{~mm}$ to $22.4 \mathrm{~mm}$ body length (BL). One of the most distinguishing characters of the larvae is the early appearance of pigmentation, starting in preflexion notochord larvae and covering the entire body in the postflexion and transformation stages, except the caudal peduncle. During the advanced postflexion stages, a typical pattern of pigmentation was observed on the base of the dorsal and anal fins. The ray formation sequence of fins is caudal, dorsal, anal, pelvic and pectoral. The sequence of the osteological development of the larvae is described, particularly of the vertebrae and caudal skeleton. Right eye migration starts at $11 \mathrm{~mm} \mathrm{BL}$ and the transformation is complete at $>23 \mathrm{~mm}$. The characters described herein allow the identification of T. naresi larvae and separate them from the larvae of other flounder species that can be found in the Patagonian region.
\end{abstract}

Key words: Paralichthyidae, fish larvae, larval fish osteology, flounders, austral fjords

\section{INTRODUCTION}

Within the Paralichthyidae family, the genus Thysanopsetta is monotypic. Its only species, T. naresi Günther, 1880 , is comparatively a small flatfish, as it grows approximately up to $15 \mathrm{~cm}$ (Nakamura 1986). Information on its general biology is scarce (e.g., Leible et al. 1974). The species inhabits both sides of southern South America, although it is more commonly found on the continental shelf of the Atlantic side. It is an abundant species in the neritic zone between $45^{\circ}$ and $50^{\circ} \mathrm{S}$ on the Pacific side and inhabits at depths between 90 and $170 \mathrm{~m}$, more frequently found south of the San Jorge Gulf $\left(47^{\circ} \mathrm{S}\right)$. In the southern extreme of its distribution reaches the coastal waters of Tierra del Fuego $\left(55^{\circ} \mathrm{S}\right)$. Inada (1986) extended the eastern distribution of T. naresi to the north of the Falkland or Malvinas islands $\left(57^{\circ} \mathrm{W}\right)$.

In the extreme south of Chile, the distribution of all flounder species is almost exclusively restricted to the channels, which would explain the endemism to the area. For example, Hippoglossina mystacium has a distribution range from $46^{\circ}$ to $50^{\circ} \mathrm{S}$ and Thysanopsetta naresi from about $42^{\circ}$ to $53^{\circ} \mathrm{S}$ (Ginsburg 1952, de Buen 1961, Leible $e t$ al. 1974). Studies on their biological characteristics as adults have been scarce, sporadic and limited. In relation to $H$. mystacium, there is only available the morphological description made on the basis of a single $183 \mathrm{~mm}$ standard 
length (SL) specimen (Ginsburg 1936). For both $H$. mystacium as well as the target species for this study, Thysanopsetta naresi, there is no knowledge of their larval stages.

The channels and fjords region of southern Chile extend approximately between $41.5^{\circ}$ and $55.0^{\circ} \mathrm{S}$ (Sievers $\&$ Silva 2006). This region is characterized by a strong dynamic display of physical and chemical factors, in addition to a complex estuarine circulation. High rainfall along with freshwater input from rivers draining from the Andes mountain creates a strong shallow halocline ( 20 $m$ deep), with low salinity values near of the fjords' head. Transport processes and larval retention occurring here, determine the location of favorable nursery areas for fish and prevent the net flow of water from transporting both eggs and larvae to the open ocean (Bernal \& Balbontín 2003).

Córdova \& Balbontín (2006) and Balbontín (2008) studied the distribution and abundance of ichthyoplankton in the southern fjords of Chile, but left the flounder species as unidentified. The purpose of this study is to describe the larvae of the southern flounder Thysanopsetta naresi, including information on the osteological development. This paper aims to contribute to the knowledge of ichthyoplankton taxonomy in southern Chile, from which there is scarce and fragmented information.

\section{Materials AND Methods}

\section{SAMPLING PROCEDURES}

The larvae were collected from plankton samples obtained onboard the research vessel 'AGOR Vidal Gormaz' during 7 cruises carried out between 1996 and 2008, ranging from $41^{\circ} 30.87^{\prime}$ to $52^{\circ} 45.10^{\prime} \mathrm{S}$ and westward up to $75^{\circ} 50.90^{\prime} \mathrm{W}$. The biological material was collected with a standard Bongo net ( $66 \mathrm{~cm}$ diameter, $300 \mu \mathrm{m}$ mesh size) fitted with TSK flowmeters. Oblique hauls took place from $200 \mathrm{~m}$ depth (or from near the bottom in the shallower stations) to surface, with a towing speed of 1-2 knots. The samples were preserved on board in $5 \%$ formalin and neutralized with sodium borate.

\section{LARVAL IDENTIFICATION AND ANALYSIS OF THE SAMPLES}

T. naresi larvae were sorted out and identified by using the serial method (Neira et al. 1998). Body measurements (Fig. 1), in a total of 74 selected individuals, were performed under a stereo-microscope using an ocular

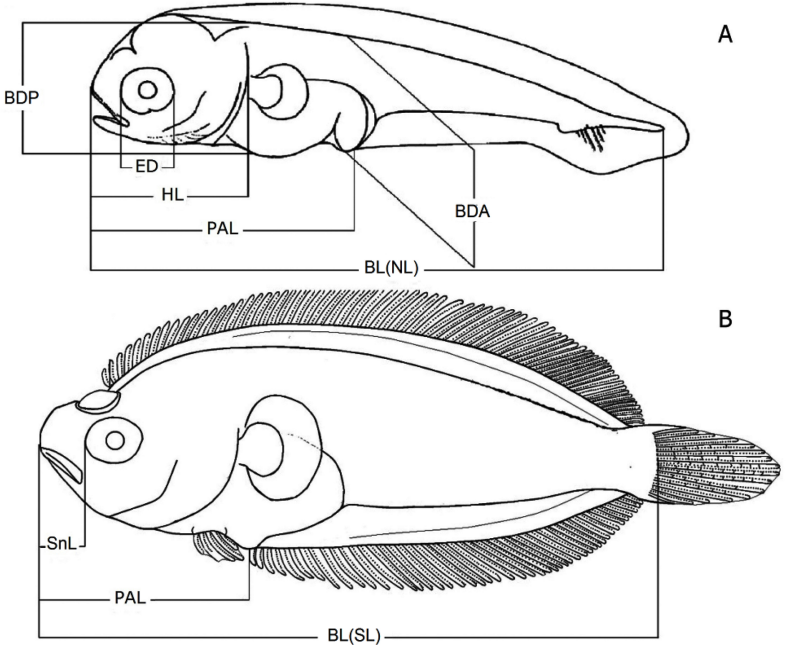

Figure 1. Hypothetical larvae displaying morphometric measurements carried out in Thysanopsetta naresi. (A) BL, body length, equivalent to notochord length (NL) in preflexion and flexion larvae. (B) BL, body length, equivalent to standard length (SL) in postflexion and transformation larvae. BDP, body depth at pectoral insert; BDA, body depth at anus; ED, eye diameter; HL, head length; PAL, preanal length; SnL, snout length / Larvas hipotéticas indicando los datos morfométricos obtenidos en Thysanopsetta naresi. (A) BL, longitud del cuerpo, correspondiente a la longitud notocordal (NL) en larvas en preflexión y flexión. (B), $B L$, longitud del cuerpo correspondiente a la longitud estándar (SL) en larvas en posflexión y transformación. BDP, altura del cuerpo a nivel de la aleta pectoral; BDA, altura del cuerpo a nivel del ano; ED, diámetro del ojo; HL, longitud de la cabeza; PAL, longitud preanal; SnL, longitud del hocico

micrometer. The terminology used in describing morphological characters and larval morphometrics were based in Moser \& Sumida (1996) and Neira et al. (1998).

The illustrations were made using a stereo-microscope provided with a camera lucida. Pigmentation refers solely to melanophores. In order to describe meristic characters and to observe the ossification development, 25 larvae encompassing the entire development size range were analyzed, using bleaching with $\mathrm{KOH}$ and staining with alizarin, following the technique modified by Hollister (1934).

\section{Results}

\section{LARVAL GEOGRAPHIC DISTRIBUTION}

Larval Thysanopsetta naresi were widely distributed within the southern study area, along the Messier, Picton and Ladrillero Channels connecting to the open ocean as 
well as in the sampling stations with direct oceanic influence such as the Darwin Channel and Guafo mouth. The northernmost station with positive presence of larvae was at the Corcovado Gulf $\left(43^{\circ} 01.73^{\prime} S\right)$. The southernmost location was the Concepcion channel (50²0.90’S) (Fig. 2).

\section{MorPHOLOGY}

The larval development of Thysanopsetta naresi from 2.8 to $22.4 \mathrm{~mm} \mathrm{BL}$ is sequentially detailed in Figs. 3A-D (Table 1). The smallest larva $(2.8 \mathrm{~mm} \mathrm{BL})$ had no identifiable remains of yolk sac, its eyes were pigmented, and the mouth was open. The body was surrounded by an embryonic finfold originated dorsally behind the cleithrum level and ending ventrally behind the anus (Fig. 3A).

Body proportions changed considerably throughout the stages of development due to growth with a significant increase in the body height (Table 1). Larvae in preflexion stage, which extends from approximately 2.8 to $6.6 \mathrm{~mm} \mathrm{BL}$ (Fig. 3A), were classified as moderately elongated with a body height of 19.7 to $33.8 \%$, at the pectoral level, and $21.2 \%$ at the anus.

Table 1. Range of morphometric data of larval Thysanopsetta naresi. Body measurements (SnL, snout length; ED, eye diameter) expressed as percentage of head length ( $\mathrm{HL}$ ), and body measurements (PAL, preanal length; BDP, body depth at pectoral insertion level, and BDA, body depth at anus) expressed as percentage of body length, $B L$; mean \pm SD / Rango de los datos morfométricos de las larvas de Thysanopsetta naresi. Medidas corporales (SnL, longitud del hocico; ED, diámetro del ojo) expresadas como porcentaje de la longitud de la cabeza $(\mathrm{HL})$ y medidas corporales (PAL, longitud preanal; BDP, altura cuerpo a nivel de la pectoral y BDA, altura del cuerpo al ano) expresadas como porcentaje de la longitud del cuerpo, BL; valores promedio $\pm \mathrm{DE}$

\begin{tabular}{lcccc}
\hline & $\begin{array}{c}\text { Preflexion } \\
\mathrm{N}=24\end{array}$ & $\begin{array}{c}\text { Flexion } \\
\mathrm{N}=18\end{array}$ & $\begin{array}{c}\text { Postflexion } \\
\mathrm{N}=21\end{array}$ & $\begin{array}{c}\text { Transformation } \\
\mathrm{N}=8\end{array}$ \\
\hline $\mathrm{BL}(\mathrm{mm})$ & $2.8-6.6$ & $6.7-9.7$ & $9.4-11.2$ & $11.2-22.4$ \\
$\mathrm{HL}$ & $20.3-32.8$ & $27.0-36.6$ & $32.2-42.8$ & $30.5-41.4$ \\
$(\% \mathrm{BL})$ & $(27.9 \pm 3.1)$ & $(31.2 \pm 2.0)$ & $(37.0 \pm 2.7)$ & $(35.6 \pm 4.3)$ \\
SnL & $12.7-27.0$ & $20.2-29.1$ & $18.5-27.7$ & $21.8-29.5$ \\
$(\% \mathrm{SnL})$ & $(21.0 \pm 3.7)$ & $(22.9 \pm 2.2)$ & $(24.3 \pm 2.2)$ & $(24.7 \pm 2.7)$ \\
ED & $27.2-43.6$ & $28.2-37.6$ & $25.1-31.7$ & $24.5-33.3$ \\
$(\% \mathrm{SnL})$ & $(36.6 \pm 4.2)$ & $(31.7 \pm 2.5)$ & $(28.2 \pm 1.8)$ & $(27.0 \pm 2.7)$ \\
PAL & $48.3-64.7$ & $47.0-56.2$ & $45.3-58.8$ & $31.8-55.0$ \\
$(\% \mathrm{BL})$ & $(54.7 \pm 3.9)$ & $(51.4 \pm 2.8)$ & $(50.9 \pm 3.6)$ & $(45.5 \pm 8.4)$ \\
BDP & $19.7-33.8$ & $26.9-35.6$ & $31.9-44.2$ & $31.0-40.5$ \\
$(\% \mathrm{BL})$ & $(28.1 \pm 3.6)$ & $(31.4 \pm 2.5)$ & $(36.2 \pm 3.0)$ & $(35.0 \pm 3.6)$ \\
BDA & $12.2-28.9$ & $21.0-35.3$ & $31.6-42.8$ & $32.5-44.2$ \\
$(\% \mathrm{BL})$ & $(21.2 \pm 4.1)$ & $(29.4 \pm 3.5)$ & $(37.5 \pm 3.3)$ & $(37.4 \pm 3.7)$ \\
\hline & & & &
\end{tabular}

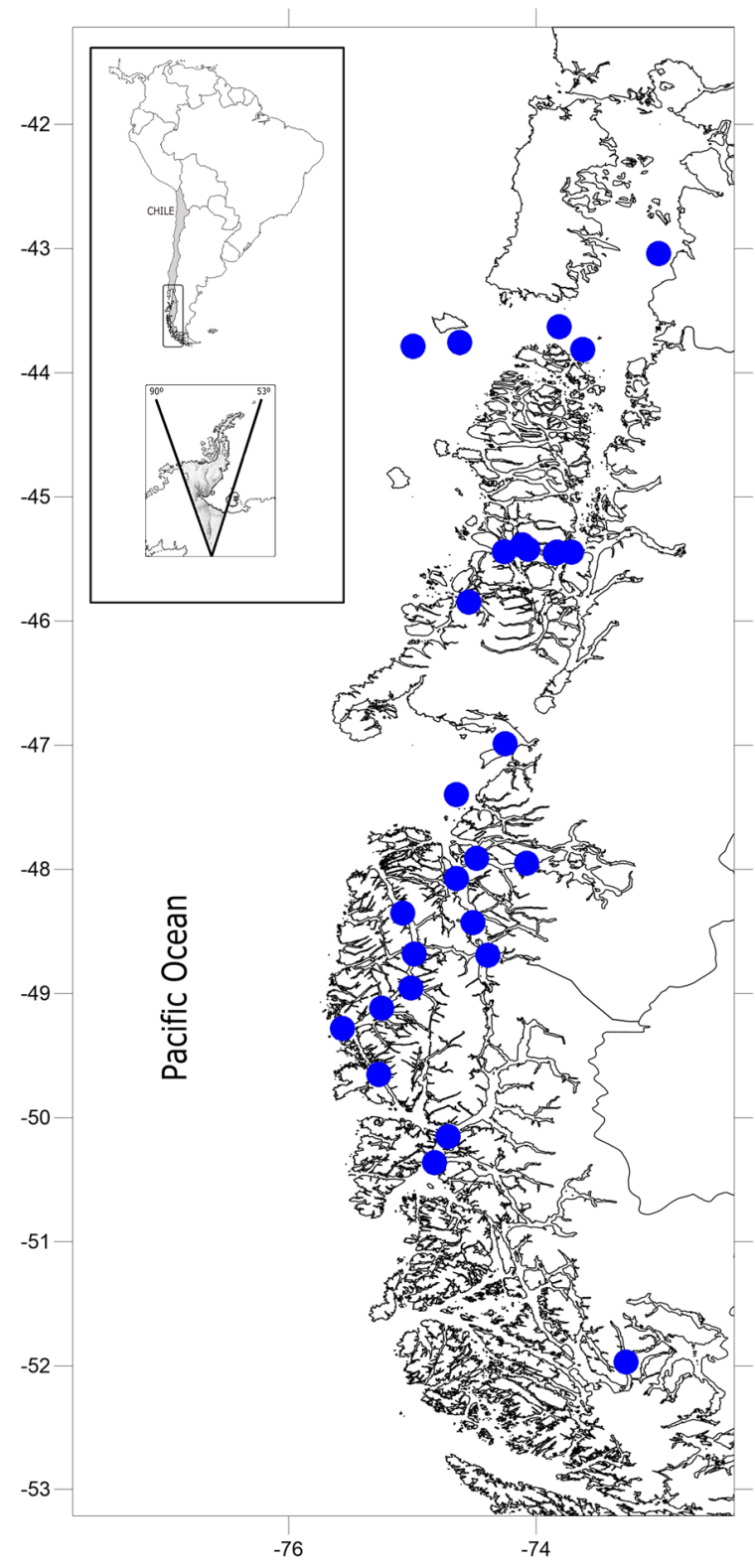

Figure 2. Surveyed area during 7 CIM AR cruises in the Patagonian fjords of southern Chile, carried out from 1996 to 2008. Circles indicate oceanographic stations with presence of Thysanopsetta naresi larvae / Área de prospección de 7 cruceros CIMAR en los fiordos patagónicos de Chile austral, realizados entre 1996 y 2008. Los círculos corresponden a las estaciones oceanográficas con presencia de larvas de Thysanopsetta naresi 
A
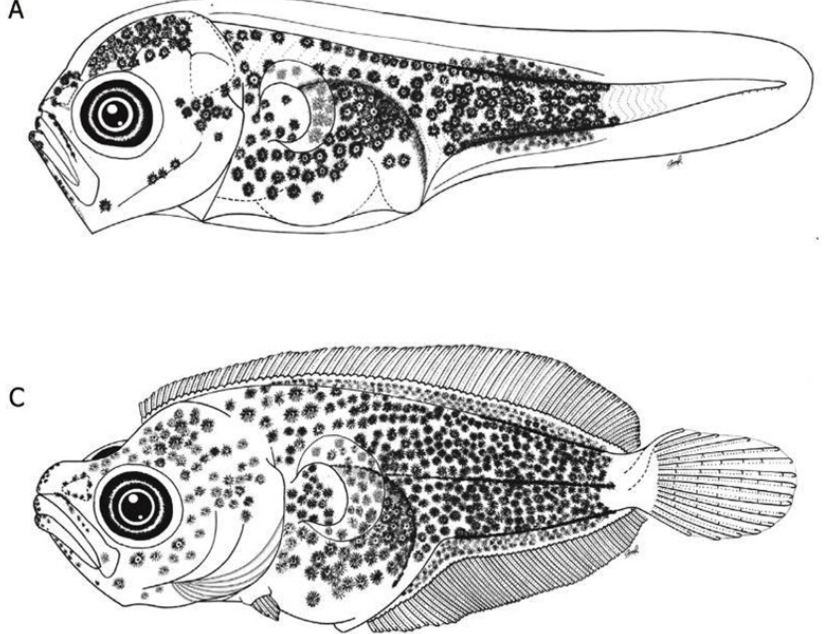

B

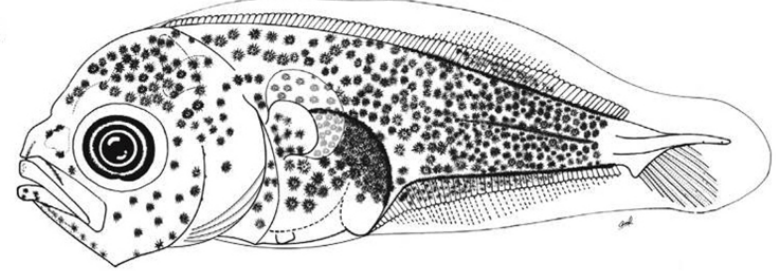

D

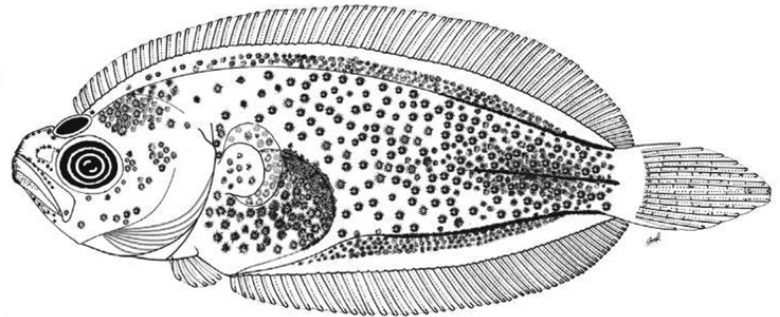

Figure 3. Developmental stages of Thysanopsetta naresi. A) $5.8 \mathrm{~mm}$ BL preflexion larva; B) $8.1 \mathrm{~mm}$ BL flexion larva; C) $11.0 \mathrm{~mm}$ BL postflexion larva; D) 22.4 mm BL transformation stage / Estadios de desarrollo de Thysanopsetta naresi. A) larva en preflexión de 5,8 mm LC; B) larva en flexión de $8,1 \mathrm{~mm} \mathrm{LC}$, C) larva en posflexión de $11,0 \mathrm{~mm}$ LC; D) larva en estadio de transformación de $22,4 \mathrm{~mm}$ LC

Notochord flexion began at approximately $6.7 \mathrm{~mm} \mathrm{BL}$ (Fig. 3B) and extended up to $9.7 \mathrm{~mm} \mathrm{BL}$. The anterior part of the body became higher towards the head region and in the middle of the body (at level of the anus). During post-flexion, from 9.4 to $11.2 \mathrm{~mm} \mathrm{BL}$, (Fig. 3C), the body became even deeper $(\mathrm{BDA}=36.2 \%)$. The height of the trunk and the anterior portion of the tail continue to increase in relation to the BL (Figs. 3A and 3B). In the transformation phase (> $11.2 \mathrm{~mm} \mathrm{BL}$ ) body proportions changed (Fig. 3D). As the body progressively deepens through development, the mean value of $35 \%$ BDP decreased in relation to earlier stages, and the body depth at the anus of the transforming larva became greater than that at the anterior part of the body $(\mathrm{BDA}=37.4 \%)$.

The deepening of body is enhanced by the great development of the basal elements of the dorsal and anal fins and the notochord flexion, which contributes to emphasize even more this effect. The relative length of the head increased during the initial larval period and then decreased in transformation stages. Throughout the early stages of development (pre-flexion and flexion) the head was moderately large, ranging from 30 to $34 \%$ BL. In post-flexion, the relative head length (HL) reached a maximum of $40 \%$ of $\mathrm{BL}$ in the $9.5 \mathrm{~mm}$ larvae, which is related to the deepening of the body. During this stage, head length was $37.0 \% \mathrm{BL}$. At the transformation stage, the HL ratio slightly decreased and at the end of this period, in the more developed larvae, the head reached about $31 \%$ BL.
In pre-flexion larvae, the $\% \mathrm{HL}$ in relation to $\mathrm{BL}$ was about $21 \%$ (Table 1), and gradually increased with larval growth. Larvae showed a concave rounded rostrum profile. In post-flexion, the relative snout length $(\mathrm{SnL})$ continued to increase and the rostrum profile became convex and bulging (Fig. 3C). During transformation, the mean $\mathrm{SnL}$ reached about $25 \%$ of the head length. The eye diameter was about $36.6 \% \mathrm{HL}$ in smaller larvae, $31.7 \%$ during notochord flexion, reaching $27 \%$ in the transformation stage. The eye migration began at about $11 \mathrm{~mm}$ BL. No specimens whose right eye was completely located on the left side of the body were recorded.

During larval development, the preanal length (PAL) was initially about half the total body length, steadily decreasing as the larva developed, as the PAL increased more slowly than the BL. In pre-flexion, when the larva was slender, PAL was $54.7 \% \mathrm{BL}$, which is considered long (Neira et al. 1998). The gut began to coil early at about 3.5 $\mathrm{mm} \mathrm{BL}$, but the uncoiled end section did not acquire its vertical position until at least $5.0 \mathrm{~mm}$ BL. In flexion stage larvae, the anus is located at a more anterior position (Fig. 3B), varying between $47 \%$ and $56 \%$ due to the coiling of the gut. When the larvae reached around $9.0 \mathrm{~mm} \mathrm{BL}$, the hypo-axial muscles began to develop over the gut. Towards post-flexion, larvae achieved a more sturdy body due to the increase in height (body and head) and the decrease of pre-anal length $(\mathrm{PAL}=50.9 \%)$. By $12.0 \mathrm{~mm}$ the hypo-axial musculature completely covered the lateral surface of the gut. During the transformation the gut had 
a moderate size (Fig. 3D). The PAL ratio decreased to $45.5 \%$ BL. The largest specimen (22.4 mm BL) had a short gut, with a pre-anal length of $32 \%$ BL.

\section{Pigmentation}

The larvae showed a heavy pigmentation throughout the development. It consisted mainly of dot melanophores, from which some expanded into stellate or dendritic. Its distribution covered the entire body, mainly on the head, trunk, visceral mass and tail, except for the caudal end at the last 5-6 myomeres.

Melanophores appear posteriorly at the anlage of the dorsal and anal fins, at approximately the same level, from behind the anus to the middle of the tail. Adjacent to these, there are rows of large melanophores on the dorsal and ventral margins of the body. Ventrally, this row extends from the anus level to the terminus of the body pigment (Fig. 3A); dorsally, it extends from the anus level all the way to the head. Small dot melanophores cover the non-pigmented margin of the tip of the tail, above and below the notochord. The head is covered by dendritic melanophores, heavily on the brain, and on the sides behind the eye and pectoral fin. There are also scattered melanophores on the snout, the tip of the upper and lower jaws and on the preopercular margin. There is almost no pigment ventrally on the head (Fig. 3A).

Flexion (6.7 to $9.7 \mathrm{~mm} \mathrm{BL}$ ) and post-flexion (9.4 to 11.2 $\mathrm{mm} \mathrm{BL}$ ) larvae experienced slight changes in the pigment pattern of the early stages. Dendritic melanophores gradually appear on the already pigmented areas of the body and areas such as the dorsal and anal pterygiophores. Melanophores also form in areas with little or no prior pigmentation, such as the snout, the preoperculum, the suborbital region, the ventral midline of the lower jaw, and the occipital region. In this stage, a line of internal pigment forms over the lateral midline of the body, and extends from behind the anus level to the point where body pigmentation ends (Figs. 3B and 3C).

Together with the formation of dorsal and anal fin pterygiophores, small melanophores develop at the sites of the first emerging rays. From post-flexion (10 mm BL) the small melanophores on the pterygiophores cover almost the entire extension of the fin bases. A striking feature of this pigmentation is that only the bases of the pterygiophores develop melanophores, leaving the distal ends unpigmented (Fig. 3D).

All larvae showed small dendritic melanophores on their jaws (Figs. 3A-D). These were concentrated at the tip of the upper jaw and along the lower jaw, following a line of pigments bordering the larva's rostrum. The maxilla exhibited a line of pigments covering the anterior and inferior part of the latter, followed by 3-4 dendritic melanophores (Fig. 3C). In post-flexion larvae, the number of punctate pigments on the lower jaw increased and was observed scattered up to the mandibular angle. The nostrils were found pigmented by small spots that surrounded them (Fig. 3C). In the gut region there were abundant dendritic melanophores. A dense internal pigmentation was found more concentrated in the peritoneal area, dorsally over the gut. Towards the ventral side of the visceral mass, melanophores were more spread or absent in some specimens. Only a few post-flexion larvae had pigmentation at the anus level.

The small punctate melanophores observed at the tip of the tail, in series of 3 to 6 dots in the ventral and dorsal margins of the notochord, decreased in number. Some persisted in the rays of the developing caudal fin. In postflexion and transformation stages, these melanophores were observed as short lines between the rays (Figs. 3C and 3D). No pigment develops on the pelvic or pectoral fin. The pigment between the caudal fin rays extended throughout its length. The melanophores on the body were distributed on the sides and the dorsal contour, forming a continuous pigmented area from the head to the tail (Fig. 3D).

\section{Meristic Characters}

The median fins begin to form in specimens larger than $5.1 \mathrm{~mm} \mathrm{BL}$, before notochord flexion. The definite number of 15 caudal rays (7 epaxial and 8 hypaxial) is reached after $9.7 \mathrm{~mm}$ BL (Table 2). The development of hypural plates and rays began at approximately $5.8 \mathrm{~mm}$ BL. They start as thickenings ventral to the notochord (Fig. 4A). The hypurals were ossified in specimens larger than 7.4 mm BL (Fig. 4B). The epural bone was observed after 8.7 $\mathrm{mm} \mathrm{BL}$, and the small upper hypural at $9.7 \mathrm{~mm} \mathrm{BL}$ (Fig. 4C). When 15 rays are observed, the upper hypural moves to an epaxial position, which occurs by $11.2 \mathrm{~mm} \mathrm{BL}$.

The caudal skeleton in the largest specimen $(22.4 \mathrm{~mm}$ BL) consisted of 5 autogenous hypurals, a final centrum formed by the fusion of 2 ural centra and the first pre-ural centrum, a free epural and a pair of uro-neurals $(\mathrm{u} 1+\mathrm{u} 2+$ pu1) partially fused with the 5th hypural (Fig. 4D). The parahypural bone was not considered as a hypural bone and is only considered as a bone splinter, with no trace of a haemal arch. Of the 16 caudal rays observed in the most 
A

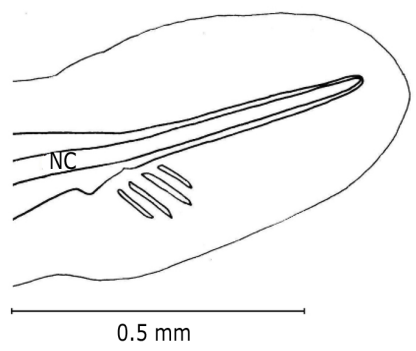

B

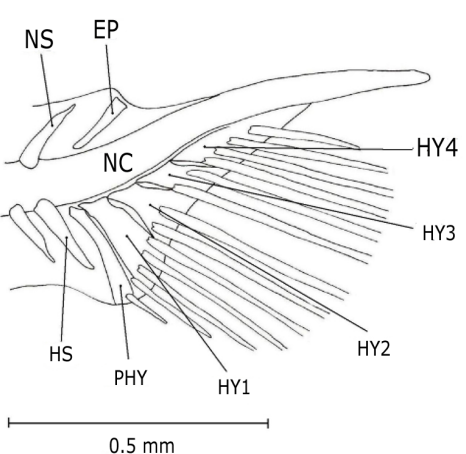

C

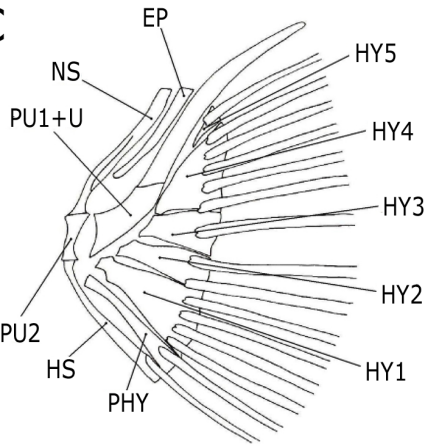

$1.0 \mathrm{~mm}$

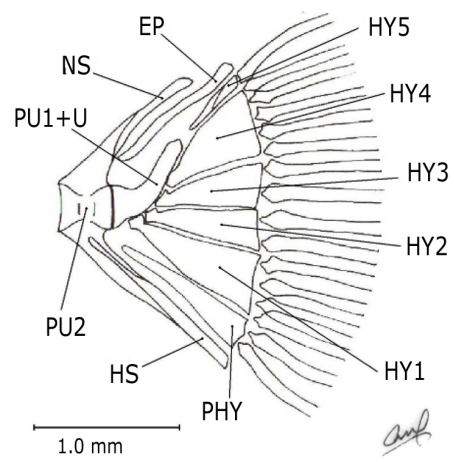

Figure 4. Caudal skeleton of Thysanopsetta naresi larvae. A) $5.8 \mathrm{~mm}$ BL larva; B) $\mathbf{7 . 4} \mathrm{mm}$ BL larva; C) $\mathbf{1 0 . 2}$ $\mathrm{mm}$ BL larva; D) $23.4 \mathrm{~mm}$ BL larva. HY 1-5=hypurals; 15, EP=epural; $P H Y=$ parahypural; NS=neural spine; HS= haemal spine; $\mathrm{PU} 2=$ preural centrum 2; $\mathrm{PU}+\mathrm{U}=$ preural centrum $1+$ ural centrum; $\mathbf{N C}=$ notochord $/$ Esqueleto caudal de las larvas de Thysanopsetta naresi. A) larva de $5,8 \mathrm{~mm} \mathrm{LC}$; B) $7,4 \mathrm{~mm} \mathrm{LC}$; C) $10,2 \mathrm{~mm} \mathrm{LC}$; D) 23,4 mm LC. HY $1-5=$ hipurales; $1-5, E P=$ epural; $P H Y=$ parahipural; NS= espina neural; $\mathrm{HS}=$ espina hemal; $\mathrm{PU} 2=$ centro preural $2 ; \mathrm{PU}+\mathrm{U}=$ centro preural $1+$ centro ural; $\mathrm{NC}=$ notocorda

Table 2. Meristic data of selected larvae of Thysanopsetta naresi. Caudal fin rays grouped between parenthesis / Datos merísticos de larvas seleccionadas de Thysanopsetta naresi. Radios caudales agrupados

\begin{tabular}{|c|c|c|c|c|c|c|c|c|}
\hline \multirow{2}{*}{$\begin{array}{c}\mathrm{BL} \\
(\mathrm{mm})\end{array}$} & \multicolumn{4}{|c|}{ Fin rays } & \multicolumn{3}{|c|}{ Vertebrae } & \multirow{2}{*}{$\begin{array}{c}\text { Branchiostegal } \\
\text { rays }\end{array}$} \\
\hline & Caudal & Dorsal & Anal & Pelvic & Precaudal & Caudal & Total & \\
\hline
\end{tabular}
entre paréntesis

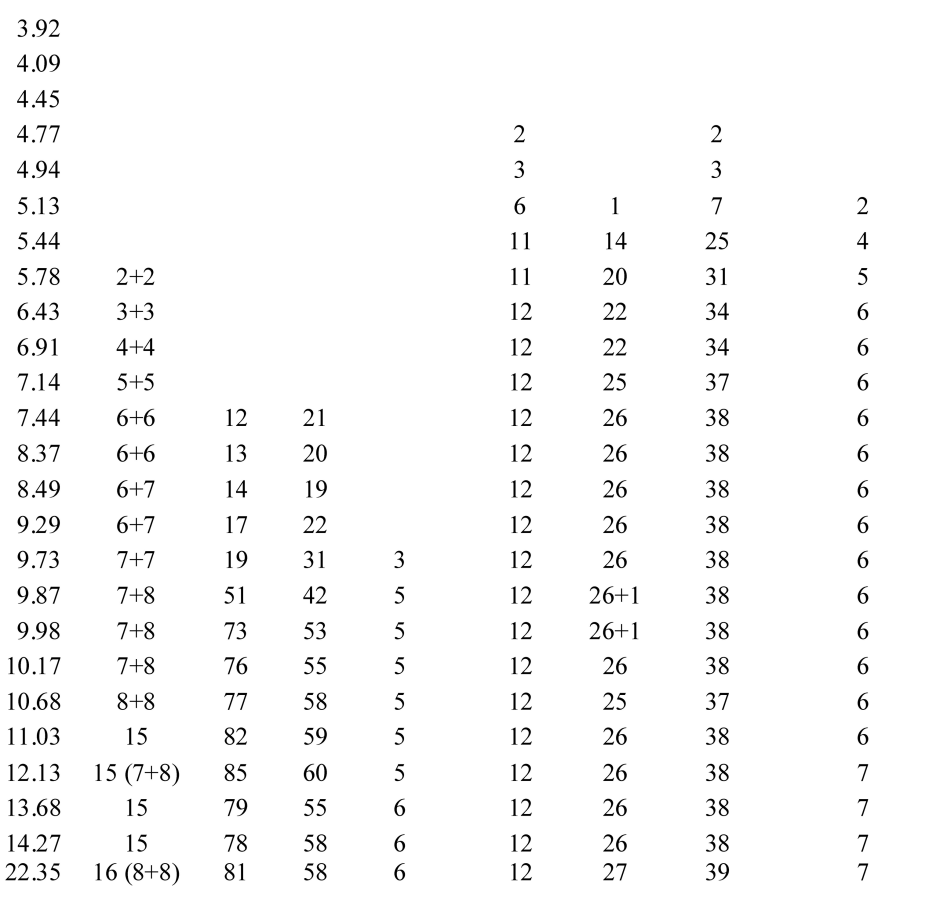


developed specimen, 13 were held by the hypural plates and 2 (ventral ends) by the parahypural bone (Fig. 4D).

The development of the dorsal and anal fins was observed in larvae as small as $4.9 \mathrm{~mm}$ BL with the emergence of anlages in embryonic fins, which reached full form in larvae of $6.5 \mathrm{~mm}$ BL. Pterygiophores in the dorsal fin began to form within the anlages, anteriorad and posteriorad, from the middle of the body. In the anal fin, they began to form caudal from behind the anus. The first rays of both fins were observed by $7.4 \mathrm{~mm} \mathrm{BL}$; between myomeres 14 and 23, 12 dorsal rays and 21 anal rays were observed. By $8.5 \mathrm{~mm} \mathrm{BL}$, the number of rays was 14 dorsal and 19 anal, and at $9.7 \mathrm{~mm} \mathrm{BL}$, they reach 19 and 31, respectively (Table 2). At $9.9 \mathrm{~mm}$ BL there is an abrupt increase to 51 dorsal and 42 anal rays. All the rays on both fins appear in post-flexion larvae larger than 10.2 $\mathrm{mm}$ BL. The ranges are 76 to 85 dorsal and 55 to 60 anal rays. Pelvic rudiments begin to form at $7.1 \mathrm{~mm}$ BL, slightly behind the cleithral symphysis, at the level of the first 2 myomeres. By $9.7 \mathrm{~mm}$ BL, 3 pelvic rays are counted and the full complement of 6 rays is observed in the $13.7 \mathrm{~mm}$ BL specimen (Table 2).

Pectoral fin buds were observed at the level of the second myomere in the smallest larva $(2.8 \mathrm{~mm} \mathrm{BL})$. Pectoral rays were not yet developed at $22.4 \mathrm{~mm}$ BL. In flexion larvae, 3 small preopercular spines were observed (Fig. 3B). These, however, were not observed in younger or older and larger larvae.

\section{FORMATION OF THE AXIAL SKELETON}

Throughout the larval development the number of myomeres remained within a range varying between 35 and 41, 11-12 pre-anal and 26-29 post-anal. Vertebrae began ossification at about $4.8 \mathrm{~mm} \mathrm{BL}$, at the same time that the caudal fin began to develop, with the vertebrae 1 and 2 being the first to form (Figs. 5A-B). The formation of neural and haemal processes was completed by $7.4 \mathrm{~mm}$ BL (Fig. 5C). Larger larvae (> $7.1 \mathrm{~mm} \mathrm{BL}$ ) had between 37 and 39 vertebrae.

Figure 5. Pattern of ossification of the axial skeleton of Thysanopsetta naresi larvae. A) $5.8 \mathrm{~mm}$ BL larva; B) $6.1 \mathrm{~mm}$ BL larva; C) $7.4 \mathrm{~mm}$ BL larva / Patrón de la osificación del esqueleto axial de Thysanopsetta naresi. A) larva de 5,8 mm LC; B) larva de 6,1 mm LC; C) larva de $7,4 \mathrm{~mm} \mathrm{LC}$

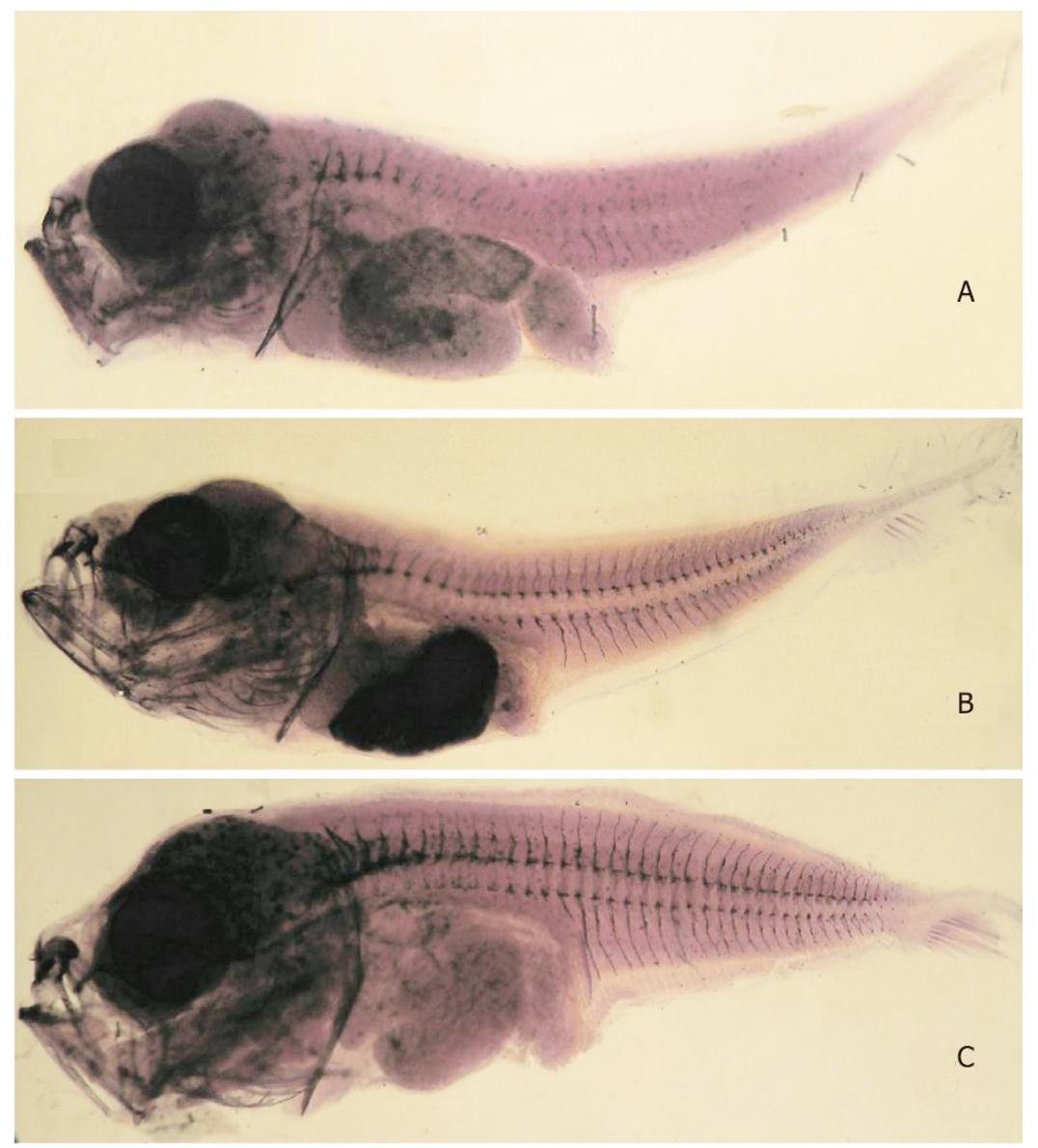


Vertebral ossification (processes and centrum) was incipient in larvae smaller than $5.4 \mathrm{~mm}$, but it becomes complete by $7.9 \mathrm{~mm}$ BL. In a $5.13 \mathrm{~mm}$ BL specimen, 6 preanal vertebrae were observed and at a level of myomere 13 , only the first caudal neural spine was found completely formed. At $5.4 \mathrm{~mm} \mathrm{BL}$, larvae already have the first 7 haemal processes from the still forming group of caudal vertebrae. Specimens larger than $6.0 \mathrm{~mm} \mathrm{BL}$, exhibited 22 formed neural processes with their respective opposing haemal processes in the caudal part of the backbone as did the 12 pre-caudal neural processes, with 4 opposing haemal processes, preceding the anus (Fig. 4B). Neural processes, except for the $7^{\text {th }}$ anterior pre-caudal vertebrae, were initially ossified by the 2 ends, that is, from the distal tip of the neural spines and the basal part of the neural arches reaching completion towards the middle part. In pre-caudal vertebrae, ossification first occurred in the portion of the arches of the $4^{\text {th }}$ anterior neural processes and only in the tips of the last 2 pre-caudal neural spines.

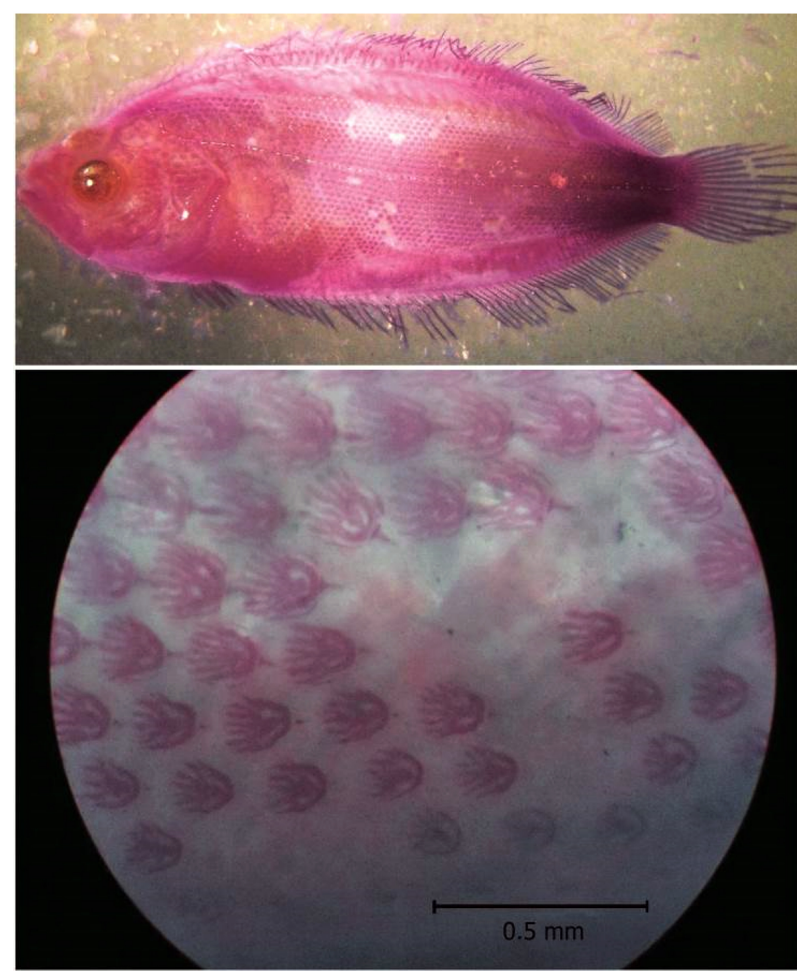

Figure 6. Larva of Thysanopsetta naresi in transformation stage stained with alizarin. Top photograph, lateral line and body surface covered with scales; bottom photograph, development of the ctenoid scales / Larva de Thysanopsetta naresi en estadio de transformación teñida con alizarina. Fotografía superior, se aprecia la línea lateral y la superficie del cuerpo cubierta de escamas. Fotografía inferior, se observa el desarrollo de escamas ctenoídeas
At $7.4 \mathrm{~mm} \mathrm{BL}$, the total number of 12 pre-caudal neural processes and 26 caudal processes (neural and haemal) were ossified (Fig. 5C). At this stage of development the larvae presented several vertebral centra in different ossification stages. During this vertebral formation stage, the larva had only three pre-anal and 11 post-anal centra ossified. The remaining 14, who had ossified neural and haemal processes, progressively developed caudad, with the exception of the last 2 vertebrae next to the urostyle (Fig. 5C). The vertebral column was fully formed at lengths above $8.2 \mathrm{~mm} \mathrm{BL}$, right after the flexion stage. The branchiostegal rays developed between 5.1 and $6.5 \mathrm{~mm}$ $\mathrm{BL}$, with the most posterior forming first, and the most anterior appearing last; the 6 rays were fully formed at 6.7 $\mathrm{mm}$ BL, during flexion. During transformation, ctenoid scales appeared over the entire body, as well as the lateral line scales on both sides of the body (Fig. 6).

\section{Discussion}

There are 9 species of the order Pleuronectiformes distributed in the southern channels and fjords of Patagonia, Chile, between $41.5^{\circ}$ and $55.0^{\circ} \mathrm{S}$. They belong to Achiropsettidae and Paralichthyidae (Sielfeld et al. 2003). Among these, only the larvae of commercially important species have been described, as is the case of Hippoglossina macrops which can be found from Mexico to Punta Arenas (Landaeta et al. 2006), Paralichthys adspersus and P. microps, distributed from Peru to $46^{\circ}$ and $50^{\circ} \mathrm{S}$ in Chile, respectively (Zuñiga \& Acuña 1992). As for Achiropsettidae of the region, their early stages have been poorly studied. In specialized literature there are only descriptions of advanced stages of Mancopsetta maculatta, based on a $12 \mathrm{~mm}$ BL larva and a few juveniles over $22 \mathrm{~mm}$ BL. In the case of Neoachiropsetta milfordi, there is only the description of a $24 \mathrm{~mm}$ BL individual (Evseenko 1996). The flounders of this family show an Antarctic and Periantarctic distribution, from $50^{\circ} \mathrm{S}$ to the south (Sielfeld et al. 2003) in the Atlantic Ocean and the Magellan Strait (Evseenko 1998).

On the coast of Chile, the distribution of adult T. naresi covers from $42^{\circ}$ to $53^{\circ} \mathrm{S}$ (De Buen 1961, Leible et al. 1974, Sielfeld \& Vargas 1999). A specimen collected by Norman (1937) near Mocha Island, extended the known range considerably further north along the Chilean coast, from $38^{\circ}$ to $53^{\circ} \mathrm{S}$. According to Inada (1986), however, the existence of $T$. naresi in Mocha Island is doubtful.

This is the first study on the early life history of the southern flounder, T. naresi, in the channels and fjords of the southeastern Pacific. The larvae including a 
transformation individual were positively identified as $T$. naresi by the correspondence of meristic data of late larvae with the meristics of adults (Menni et al. 1984, Inada 1986), the pattern of the caudal skeleton (unique within Paralichthyidae) and the presence of a nearly straight lateral line. The small individuals still lacking bone structures were connected to the larval series by means of the pigmentation pattern, which is characterized by three horizontal lines of very dense inner tail melanophores and very dense pigmentation in the rays of the dorsal and anal fins of small larvae.

There are a few morphological differences between the larvae and the adults of $T$. naresi. These differences can be clearly seen when comparing the metamorphosing 22.4 mm specimen studied here, with the adult images provided by Inada (1986), Norman (1937) and Menni et al. (1984), which show a partially straight upper profile of the snout, whereas in the larva it is markedly concave, as well as a smaller relative size of the head, eyes, nose and pre-anal length of both, juveniles and adults compared with the larva. As the smallest juvenile examined by Menni et al. (1984), is more than twice the size of the transforming larva of Fig. 2D, these morphological differences might be the result of the progressive development and transition of the larva to a juvenile.

The specific identification of $T$. naresi is confirmed after examining the caudal structure and compares it with that in the species from the southern part of Chile. The genera Thysanopsetta and Tephrinectes (both belonging to Paralichthyidae) have, exceptionally within the family, the most primitive caudal ossification pattern within the Pleuronectiformes, with hypurals 1-4 not fused to the centrum end or with each other (Hensley \& Ahlstrom 1984).

Interestingly, T. naresi is the only species with this type of hypural complex in the family Paralichthyidae, whereas the other species have a hypural complex with fused hypural 1 and 2 (hypural plate I). This produces an element that articulates with the rear-ventral surface of the urostile and the fused hypurals 3 and 4, forming the final portion of the middle centrum (Flores \& de la Hoz 2010).

The larvae of Paralichthyidae have small preopercular spines (Ahlstrom et al. 1984). Some of the species in the genus Paralichthys have small front sphenotic spines (Zuñiga \& Acuña 1992). In T. naresi, the preopercular spines are tiny, almost imperceptible, and apparently transitory as they were observed only in small specimens. Problems with decalcification of the bone in preserved specimens, may contribute to make it more difficult to stain and observe them. The shape of the lateral line observed in larvae is consistent in with the one described by Menni et al. (1984) for adults of T. naresi. It is almost straight and well developed on both sides of the body, similar to that in Neoachiropsetta milfordi and Mancopsetta maculata (Achiropsettidae) (Evseenko 1998).

The main differences in larval pigmentation found among the larvae of the local species of the family Paralichthyidae are summarized in Table 3. This is useful for identification purposes, especially during pre-flexion. Distinguishing pigmentation characteristics of larval $T$. naresi are a more homogeneous melanophore distribution in the trunk and the presence of three very dense internal pigment lines along the lateral midline and under the base of the dorsal and anal fins. Actually, these bands allow the identification of the smallest larvae of $T$. naresi.

During pre-flexion, T. naresi develops a pigment patch in the dorsal finfold, near the midpoint between the anus and the tail tip, which is absent in larval H. macrops (Landaeta et al. 2006). Both species display a pigment patch in the anal finfold. The absence newly hatched yolk-sac larvae of $T$. naresi, suggests that hatching occurs at less than $3 \mathrm{~mm} \mathrm{BL}$.

The sharp increase in tail depth appears to be correlated with the development of both epaxial and hypaxial muscles, resulting in a significant change in body shape, from an elongate pre-flexion larva to a more robust flexion specimen. In Pleuronectiformes, this process typically occurs between 10 and $25 \mathrm{~mm} \mathrm{BL}$ (Ahlstrom et al. 1984). However, the minimum size at which it ends (eye migration included) can be as small as $4.1 \mathrm{~mm}$ long and as large as $72 \mathrm{~mm}$ BL (Osse \& Van den Boogaart 1997). In T. naresi, transformation begins at almost the same size as in $H$. macrops, up to approximately $11 \mathrm{~mm}$. The southern flounder ( $T$. naresi) metamorphosis spread at a wider range to what was described for the transforming larvae of the big-eye flounder (H. macrops). Similar to Mancopsetta maculata and Achiropsetta tricholepis, $T$. naresi has a lengthy transformation and juvenile phase (Evseenko 1998), and it might even extends beyond 22.4 $\mathrm{mm}$ BL, since the eye has not acquired its final position on the zenith side. This process occurs just below the origin of the dorsal fin (Fig. 2D) and in juveniles and adults, the dorsal fin is located in front of the eye's anterior margin (Inada 1986). Eye migration in H. macrops larvae occurs in an anterior position with regards to the origin of the dorsal fin; in $H$. mystacium juvenile specimens the origin of dorsal fin is almost at the level of the middle of the eye; in P. adspersus juveniles the origin of the dorsal fin is between the level of the anterior margin of the eye 
Table 3. Summary of larval characters useful to distinguish among species of the family Paralichthyidae inhabiting the austral region of Chile. Morphology expressed as body length $(\mathrm{mm})$ / Resumen de los caracteres larvales, útiles para distinguir entre especies de la familia Paralichthyidae que habitan en la región austral de Chile. La morfología expresada en longitud corporal (mm)

\begin{tabular}{|c|c|c|c|c|}
\hline Character & Thysanopsetta naresi & Hippoglossina macrops & Paralichthys microps & Paralichthys adspersus \\
\hline \multicolumn{5}{|l|}{ Morphology } \\
\hline Size range of yolk-sac larvae & $<2.8$ & $4.4-5.7$ & 1.5 & 1.7 \\
\hline $\begin{array}{l}\text { Size range of larvae in } \\
\text { notochord pre-flexion stage }\end{array}$ & $2.8-6.6$ & $4.5-7.8$ & $2.95-6.0$ & $3.6-7.0$ \\
\hline $\begin{array}{l}\text { Size range of larvae in } \\
\text { notochord flexion stage }\end{array}$ & $6.7-9.7$ & $7.7-9.4$ & $6.2-7.2$ & $6.9-8.6$ \\
\hline $\begin{array}{l}\text { Size range of larvae in } \\
\text { notochord post-flexion stage }\end{array}$ & $9.4-11.2$ & $8.2-11.6$ & $6.0-7.8$ & $8.4-9.4$ \\
\hline $\begin{array}{l}\text { Size range of larvae in } \\
\text { transformation stage }\end{array}$ & $11.2-23.4$ & $11.1-16.6$ & $8.1-18.0$ & $9.2-15.0$ \\
\hline Head spines & Preopercular & Preopercular & $\begin{array}{l}\text { Preopercular and } \\
\text { sphenotics }\end{array}$ & $\begin{array}{l}\text { Preopercular and } \\
\text { sphenotics }\end{array}$ \\
\hline \multicolumn{5}{|l|}{ Meristic data } \\
\hline Anterior elongated dorsal fin rays & 0 & 0 & 6 & 3 \\
\hline Dorsal fin rays & $78-90^{1}$ & $63-73^{2}$ & $71-80^{3}$ & $72-77^{4}$ \\
\hline Anal fin rays & $56-67^{1}$ & $52-58^{2}$ & $57-64^{3}$ & $57-65^{4}$ \\
\hline Precaudal vertebrae & 12 & $9-10$ & 10 & 10 \\
\hline Postcaudal vertebrae & $26-(27)$ & $27-28$ & 27 & 24 \\
\hline \multicolumn{5}{|l|}{ Pigmentation } \\
\hline $\begin{array}{l}\text { Embryonic finfold of the early } \\
\text { larvae }\end{array}$ & $\begin{array}{l}\text { Opposite aggregations of } \\
\text { pigments in the midpoint of } \\
\text { the tail, and in the base of } \\
\text { the dorsal and anal } \\
\text { embryonic finfold }\end{array}$ & $\begin{array}{l}\text { Pigment grouping in the } \\
\text { anal embryonic finfold, in } \\
\text { the midpoint between the } \\
\text { anus and the tip of the tail }\end{array}$ & $\begin{array}{l}\text { Dorsal and anal } \\
\text { embryonic finfold with } \\
\text { pigments }\end{array}$ & $\begin{array}{l}\text { Dorsal embryonic } \\
\text { finfold unpigmented; } \\
\text { anal embryonic finfold } \\
\text { heavily pigmented }\end{array}$ \\
\hline $\begin{array}{l}\text { Trunk and tail in the notochord } \\
\text { flexion larval stage }\end{array}$ & $\begin{array}{l}\text { Three internal pigment } \\
\text { stripes in the lateral midline } \\
\text { and under the dorsal and } \\
\text { anal fin base }\end{array}$ & $\begin{array}{l}\text { Aggregation of vertical } \\
\text { pigments in the midpoint } \\
\text { between anus and caudal } \\
\text { fin }\end{array}$ & $\begin{array}{l}\text { Dense zone of } \\
\text { melanophores in the } \\
\text { posterior middle part } \\
\text { of the tail }\end{array}$ & $\begin{array}{l}\text { Melanophores } \\
\text { concentrated in the } \\
\text { ventrolateral region of } \\
\text { the trunk and tail }\end{array}$ \\
\hline $\begin{array}{l}\text { Hypaxial zone, head and visceral } \\
\text { mass }\end{array}$ & Almost unpigmented & Heavily pigmented & $\begin{array}{l}\text { Scarse pigmentation in } \\
\text { head }\end{array}$ & Abundant pigmentation \\
\hline $\begin{array}{l}\text { Punctuate pigments in the tip of } \\
\text { the notochord or caudal } \\
\text { peduncle }\end{array}$ & $\begin{array}{l}\text { In a series of } 3 \text { to } 6 \text { in the } \\
\text { ventral and dorsal contour of } \\
\text { the tip of the notochord }\end{array}$ & $\begin{array}{l}\text { In a row in the ventral } \\
\text { contour of the tip of the } \\
\text { notochord }\end{array}$ & $\begin{array}{l}\text { In a row in the dorsal } \\
\text { and ventral contour of } \\
\text { the la notochord }\end{array}$ & $\begin{array}{l}\text { In a row near the tip tip } \\
\text { of the notochord }\end{array}$ \\
\hline $\begin{array}{l}\text { Base of pectoral fin before the } \\
\text { formation of the caudal fin }\end{array}$ & $\begin{array}{l}\text { A few melanophores } \\
\text { scattered in the anterior part } \\
\text { of the base of the pectoral } \\
\text { fin }\end{array}$ & $\begin{array}{l}\text { Anterior punctuate } \\
\text { melanophores in the base } \\
\text { the pectoral fin }\end{array}$ & Lacking & Scarse \\
\hline
\end{tabular}

In Hippoglossina mystacium the counts for fin rays are D 66; A 55; pelvic 11 (Ginsburg 1952)

Source: ${ }^{1}$ Menni et al. (1984); ${ }^{2}$ Pequeño \& D'Ottone (1987); ${ }^{3 \text { and } 4}$ Nakamura (1986)

and the pupil; in P. microps, the origin of the dorsal fin is located slightly before the level of the center of the eye (Zuñiga \& Acuña 1992).

Furthermore, larval T. naresi is similar to that of the Hippoglossina macrops, being the most notorious differences in the heavy pigment distribution in the body and caudal end of the first species, together with different dorsal ray formation sequence. Larvae of southern flounder differ from the Paralichthys microps and $P$. adspersus larvae since both Paralichthys possess markedly elongated spines and anterior dorsal rays that are not found in $T$. naresi.

\section{ACKNOWLEDGEMENTS}

The authors thank the deck crew and biologists involved in sampling onboard the research vessel 'AGOR Vidal Gormaz'. This study was partially funded by CIMAR 2 Fjord, CIMAR 4 Fjord, CIMAR 8 Fjord and CONA - C11F 05-02 projects awarded to F. Balbontin. The comments of two anonymous reviewers improved the quality of the manuscript. 


\section{LITERATURE CITED}

Ahlstrom E, K Amaoka, D Hensley, HG Moser \& B Sumida. 1984. Pleuronectiformes: Development. In: Moser HG, W Richards, D Cohen, M Fahay, A Kendall \& S Richardson (eds). Ontogeny and systematic of fishes. Special Publication 1: 640-670. American Society of Ichthyologists and Herpetologists, Kansas.

Balbontín F. 2008. Ichthyoplankton in the austral Chilean channels and fjords. In: Silva N \& S Palma (eds). Progress in the oceanographic knowledge of Chilean interior waters, from Puerto Montt to cape Horn, pp. 115-120. Comité Oceanográfico Nacional, Pontificia Universidad Católica de Valparaíso, Valparaíso.

Bernal R \& F Balbontín. 2003. Distribución y abundancia de las larvas de peces desde el estrecho de Magallanes al cabo de Hornos. Ciencia y Tecnología del Mar 26(1): 85-92.

Córdova G \& F Balbontín. 2006. Distribución espacial de la abundancia y de la talla de ocho tipos de larvas de peces entre la boca del Guafo y bahía Anna Pink, zona austral de Chile. Ciencia y Tecnología del Mar 29(1): 153-161.

De Buen F. 1961. Peces chilenos. Familias Alepocephalidae, Muraenidae, Sciaenidae, Scorpaenidae, Liparidae y Bothidae. Montemar 11: 1-52.

Evseenko S. 1996. Early development stages of flounders of the Southern Ocean (Family Achiropsettidae). Journal of Ichthyology 36(4): 345-349.

Evseenko S. 1998. Ontogeny and relationships of the flatfishes of the Southern Ocean (Achiropsettidae, Pleuronectoidei). Journal of Ichthyology 36(6): 725-752.

Flores H \& E de la Hoz. 2010. Osteología de Hippoglossina macrops (Pleuronectiformes, Paralichthyidae). Revista de Biología Marina y Oceanografía 45: 547-563.

Ginsburg I. 1936. Description of a new flatfish, with notes on related species. Journal of the Washington Academy of Sciences 26(3): 128-133.

Ginsburg I. 1952. Flounders of the genus Paralichthys and related genera in American waters. Fishery Bulletin 52: 1-51.

Hensley D \& E Ahlstrom. 1984. Pleuronectiformes: Relationships. In: Moser H, W Richards, D Cohen, M Fahay, A Kendall \& S Richardson (eds). Ontogeny and systematics of fishes. Special Publication 1: 670-687. American Society of Ichthyologists and Herpetologists, Kansas.

Hollister G. 1934. Clearing and dyeing fish for bony study. Zoologica 12(10): 89-101.

Inada T. 1986. Bothidae. In: Nakamura I, T Inada, M Takeda \& H Hatanaka (eds). Important fishes trawled off Patagonia, pp. 306-307. Japan Marine Fishery Resource Research Center, Tokyo.

Landaeta MF, G Herrera, M Pedraza, CA Bustos \& LR Castro. 2006. Reproductive tactics and larval development of bigeye flounder, Hippoglossina macrops off central Chile. Journal of Marine Biological Association of the United Kingdom 86: 1253-1264.

Leible M, R Pinto \& C Donoso. 1974. Análisis taxonómico de atributos y caracteres merísticos del lenguado austral, Thysanopsetta naresi (Pisces: Bothidae). Investigaciones Oceanológicas Chilenas, Universidad Católica de Chile, Talcahuano 1(2): 17-26

Menni RC, ML Garcia \& MB Cousseau. 1984. Pleuronectiformes de laArgentina, II. Thysanopsetta naresi (Bothidae, Paralichtinae). Historia Natural, Argentina 4(2): 13-18.

Moser HG \& B Sumida. 1996. Paralichthyidae. In: Moser HG (ed). The early stages of California current region. California Cooperative Oceanic Fisheries Investigations, Atlas 33: 1325-1356.

Nakamura I. 1986. Bothidae. In: Nakamura I, T Inada, M Takeda \& H Hatanaka (eds). Important fishes trawled off Patagonia, pp. 294-297. Japan Marine Fishery Resource Research Center, Tokyo.

Neira FJ, A Miskiewicz \& T Trnski. 1998. Larvae of temperate Australian fishes. Laboratory guide of larval fish identification, 474 pp. University of Western Australia Press, Nedlands.

Norman JR. 1937. Coast fishes part II. The Patagonian region. Discovery Reports 16: 1-150.

Osse JW \& JG Van den Boogaart. 1997. Size of flatfish larvae at transformation, functional demands and historical constraints. Journal of Sea Research 37: 229-239.

Pequeño G \& E D'Ottone. 1987. Diferenciación taxonómica de los lenguados comunes de Valdivia Chile (Osteichthyes, Bothidae). Revista de Biología Marina 23(1): 107-137.

Sielfeld W \& M Vargas. 1999. Review of marine fish zoogeography of Chilean Patagonia $\left(42^{\circ}-57^{\circ} \mathrm{S}\right)$. Scientia Marina 63(1): 451-463.

Sielfeld W, M Vargas \& I Kong. 2003. Primer registro de Etropus ectenes Jordan, 1889, Bothus constellatus Jordan \& Goss, 1889, Achirus klunzingeri (Steindachner, 1880) y Symphurus elongatus (Günther, 1868) (Pisces, Pleuronectiformes) en Chile, con comentarios sobre la distribución de los lenguados chilenos. Investigaciones Marinas 31(1): 1-28.

Sievers H \& N Silva. 2006. Masas de agua y circulación en los canales y fiordos australes. En: Silva N \& S Palma (eds). Avances en el conocimiento oceanográfico de las aguas interiores chilenas, Puerto Montt a cabo de Hornos, pp. 53-58. Comité Oceanográfico Nacional / Pontificia Universidad Católica de Valparaíso,Valparaíso.

Zuñiga HN \& ES Acuña. 1992. Larval development of two sympatric flounders, Paralichthys adspersus (Steindachner, 1867) and Paralichthys microps (Gunther, 1881) from the Bay of Coquimbo, Chile. Fishery Bulletin 90: 607-620. 